\title{
Pkm Kelompok Usaha Produksi dan Penjualan Pudak Di Kecamatan Gresik Kabupaten Gresik Provinsi Jawa Timur
}

\author{
Suwanto $^{1}$, Roihatul Zahroh ${ }^{2}$, Chabib Bahari ${ }^{3}$ \\ suwantofatima@gmail.com \\ 1,2Prodi Ilmu Keperawatan, Fakultas Ilmu Kesehatan, Universitas Gresik \\ ${ }^{3}$ Prodi Manajemen, Fakultas Ekonomi, Universitas Gresik
}

\begin{abstract}
Abstrak: Limbah ampas kelapa selama ini tidak dimanfaatkan oleh kedua mitra kelompok usaha produksi dan penjualan pudak, hal ini dikarenakan kedua mitra tersebut tidak mengenal tentang pemanfaatan dari ampas kelapa. Ampas kelapa dapat dimanfaatkan sebagai produk makanan seperti tepung kelapa, roti kelapa dan pudak, sebelum ampas kelapa di buat sebagai bahan produk makanan, ampas kelapa diproses terlebih dahulu sehingga mendapatkan mutu dan kualitas yang bagus dari produk makanan yang telah dibuat. Berdasar program PKM bagi kedua kelompok usaha produksi dan penjualan pudak adalah mendapatkan nilai tambah dari pemanfaatanampas kelapa yang selama ini tidak dimanfaatkan dan mengganggu pencemaran lingkungan sekitar. Untuk mencapai target ini dapat dicapai melalui tutorial dan praktek oleh tim pengusul PKM. Dapat disimpulkan bahwa kegiatan program kemitraan masyarakat telah dilakukan pada tanggal 26 Mei 2018 di Kelurahan Sukodono Kecamatan Gresik. Adapun hasil kegiatan yang telah dilakukan dapat diperoleh kesimpulan sebagai berikut: (1) antusias kedua mitra dan keluarga mitra dalam mengikuti kegiatan tersebut hingga selesai, banyak pertanyaan yang telah diajukan dikarenakan selama ini belum mengenal pemanfaatan ampas kelapa digunakan sebagai produk makanan, tidak perna melakukan pemasaran melalui e-comersial dan tidak perna menghitung harga pokok produksi dan harga jula produk. (2) Pemanfaatan ampas kelapa dapat dibuat produk makanan seperti tepung kelapa, roti kelapa dan pudak dengan aroma yang khas kelapa, rasa kelapa dan penampilannya juga bagus. Adapaun produk makanan tersebut yang telah dibuat maka dapat menambah penghasilan bagi kedua mitra dan keluarga mitra usaha produksi dan penjualan pudak. (3) Penggunaan website ecomersial dapat mempermuda kedua mitra untuk memasarkan hasil produk yang telah dibuat. Adapun manfaat pemasaran menggunakan website ecomersial adalah hemat waktu, hemat uang, dan hemat tenaga.(4) Kedua mitra usaha produksi dan penjualan pudak dapat menghitung biaya bahan baku, tenaga kerja langsung, biaya over head produksi sehingga dapat menimalisir kerugihan, dan mengetahui berapa keuntungan yang telah didapatkan dari hasil produksinya.
\end{abstract}

Kata Kunci: Limbah ampas kelapa, tepung kelapa, roti kelapa, pudak.

\section{ANALISIS SITUASI}

Kabupaten Gresik dikenal dengan Kota Wali karena di sana terdapat makam para Wali antara lain Maulana Malik Ibrahim dan Sunan Giri yang merupakan pembawa dan penyebar 
agama islam di Kabupaten Gresik. Keberadaan makam para Wali di Kabupaten Gresik maka dapat dijadikan sebagai objek wisata religi. Objek wisata tersebut banyak dikunjungi oleh wisatawan dari luar Kabupaten untuk berziarah di kedua makam. Kawasan tempat makam dan di sepanjang jalan Kota Gresik banyak ditemui makanan khas Gresik adalah pudak. Banyak wisatawan berziarah ke makam membeli makanan pudak sebagai oleh-oleh. Masyarakat Kabupaten Gresik memproduksi dan menjual pudak, kebanyakan yang memproduksi dan menjual pudak adalah ibu rumah tangga. Adanya produksi dan penjualan pudak dapat mensuplai kebutuhan perekonomian keluarga. Produksi dan penjualan pudak yang dikelolah oleh ibu rumah tangga dapat meminimalisir angka pengangguran dan kemiskinan serta menciptakan peluang kerja bagi orang-orang yang belum mendapatkan pekerjaan.

Produksi dan penjual pudak yang telah dilakukan oleh Ibu Prihatin dan Ibu Emiliyana Hendrayani yang beralamatkan di Kelurahan Sukodono dan Kelurahan Tlogopojok Kecamatan Gresik Kabupaten Gresik. Rumah kedua kelompok usaha tersebut berjarak 3 km dari Kampus Universitas Gresik, kedua kelompok usaha tersebut selama ini konsisten menjalankan usaha produksi dan penjual pudak. Seiring dengan meningkatnya jumlah kapasitas produksi dan penjual pudak, maka jumlah kebutuhan bahan baku seperti tepung sagu, kelapa, gula pasir semakin banyak. Menurut kedua kelompok usaha tersebut ampas dari kelapa dibuang yang dimanfaatkan adalah santan. Seiring dengan meningkatnya jumlah kapasitas produksi dan penjualan pudak, maka jumlah ampas kelapa semakin meningkat. Saat ini produksi pudak oleh Ibu Prihatin dan Ibu Emiliyana Hendrayani membutuhkan tepung sagu $10 \mathrm{~kg}$ per hari dan 20 butir kelapa. Sedangkan ampas dari 20 butir kelapa sebanyak $4 \mathrm{~kg}$ limba ampas yang dibuang setiap harinya.

Selama ini limbah ampas kelapa tidak dimanfaatkan, limbah ampas kelapa dibuang di belakang rumah dapat menimbulkan bau busuk yang tidak sedap. Selain menimbulkan bau tidak sedap, limbah ampas kelapa berpotensi menjadi sarang binatang kecil penggangu dan serangga lain seperti tikus, ular, lalat, nyamuk. Binantang tersebut sangat berpotensi menjadi bibit penyakit yang membahayakan kesehatan tubuh (Pratiwi dkk, 2016). Telah dilaporkan oleh Bonzon, J.A. and J.r. Velasco, 1882 dalam Putri Fajri Meddiati, 2010 bahwa tepung dari ampas kelapa memiliki kandungan lemak $12,2 \%$, protein $18,2 \%$, serat kasar $20 \%$, abu 4,9\%, dan kadar air 6,2\%. Sedangkan menurut (Yulvianti Meri dkk, 2015) bahwa tepung kelapa mempunyai sumber protein yang baik, kandungan proteinnya sekitar 23\% lebih besar dibandingkan dengan gandum. Tepung kelapa mempunyai kandungan serat yang cukup tinggi. Kandungan serat pada tepung kelapa dapat mengontrol pelepasan glukosa seiring 
Suwanto $^{1}$, Roihatul Zahroh ${ }^{2}$, Dkk.

waktu, sehingga dapat dimanfaatkan sebagai diet makanan pada pasien penderita penyakit diabetes mellitus dan obesitas (Trinidad P Trinidad et al, 2006; Fauzan Muthia, 2013). Serat pangan dalam jumlah yang cukup tinggi didalam makanan sangat baik untuk pencernaan dalam usus (Ramulu dan Rao, 2003 dalam Yulvianti Meri dkk, 2015). Serat pangan tidak dapat dicerna dan tidak diserap oleh saluran pencernaan manusia, tetapi memiliki fungsi yang sangat penting bagi pemeliharaan kesehatan, pencegahan penyakit dan sebagai komponen penting dalam terapi gizi (Astawan, 2004 dalam Yulvianti Meri dkk, 2015 ).

Usulan program kemitraan masyarakat (PKM) akan di orientasikan pada pemanfaatan limbah ampas kelapa menjadi produk baru yang mampu memberikan peningkatan nilai tambah dengan cara mengolah limbah ampas kelapa menjadi tepung yang dimanfaatkan sebagai bahan baku pembuatan roti kelapa dan pudak. Produksi roti kelapa bahan utama adalah tepung terigu, dimana tepung terigu bahan bakunya terbuat dari gandum. Gandum didapatkan dari luar negeri sehingga sulit untuk ditemukan serta harganya mahal. Tepung terigu dapat digantikan dengan tepung kelapa. Sedangkan bahan baku utama produksi pudak selama ini menggunakan tepung sagu. Kandungan pada tepung sagu yang paling banyak adalah karbohidrat. Diet bagi penyakit diabetes memanfaatkan makanan yang kaya dengan serat serta kandungan proteinnya banyak adalah tepung kelapa.

Kedua kelompok usaha yang memproduksi pudak setiap harinya membutuhkan $10 \mathrm{~kg}$ gram tepung sagu dan 20 butir kelapa, dimana 20 butir mendapatkan tepung sebanyak $4 \mathrm{~kg}$ perhari, dalam satu minggu mendapatkan tepung kelapa sejumlah $28 \mathrm{~kg}$. Tepung kelapa dijual dengan berat 100 gram sebanyak Rp. 3.000, jika 28 kg tepung kelapa di kemas dengan berat 100 gram mendapatkan 280 kemasan tepung kelapa. Maka mendapatkan keuntungan Rp. 8.40.000. Produksi pembuatan roti dengan bahan tepung kelapa sebanyak $28 \mathrm{~kg}$ dihasilkan 448 toples dengan berat bersih 160 gram per toples. Harga roti kelapa per toples dengan berat 160 gram adalah Rp. 30.000, jika 448 toples roti kelapa dijual maka mendapatkan keuntungan sebanyak Rp. 13.440.000. Adapun pembutan pudak menggunakan tepung kelapa $28 \mathrm{~kg}$ mendapatkan 1680 butir pudak. Harga pudak Rp 25.000 mendapatkan 1 ikat dengan jumlah 10 butir pudak, kalau 168 pudak per 1 ikat mendapatkan keuntungan sebanyak Rp. 4.200.000.

Selain masalah limbah ampas kelapa yang menjadi masalah kedua kelompok usaha tersebut adalah pemasaran pudak ke luar Kabupaten, setelah dilakukan wawancara terhadap kedua kelompok usaha produksi dan penjual pudak merasa kesulitan untuk memasarkan hasil produksinya karena terikat dengan waktu dan tenaga. Selama ini kedua kelompok usaha 
Suwanto $^{1}$, Roihatul Zahroh ${ }^{2}$, Dkk.

hanya memproduksi dan menjual pudak didalam Kabupaten saja tanpa menjual ke luar Kabupaten. Kedua kelompok usaha mengharapkan agar usaha produksi dan penjualan pudak sampai terjual ke luar Kabupaten sehingga dapat memproduksi pudak lebih banyak lagi. Adapun masalah pembukuan tentang penjualan pudak kedua kelompok usaha tidak bisa menjawab tentang penghasilan dan kerugian tiap bulanya karena tidak dibukukan. Selama ini kedua kelompok usaha produksi dan penjual pudak ketika mendapatkan uang dari hasil jualannya kemudian uang hasil jualan tersebut digunakan untuk modal pembelihan bahan baku untuk produksi pudak.

\section{Permasalahan Mitra}

Berdasarkan kondisi kedua kelompok usaha produksi dan penjual pudak di Kabupaten Gresik, maka pengusul program PKM dapat mengidentifikasi beberapa permasalahan yang dialami kedua kelompok usaha tersebut antara lain;

1. Produksi dan pejual pudak di Kabupaten Gresik yang selama ini bahan baku yang digunakan untuk produksi adalah tepung sagu, kelapa, gula pasir. kelapa yang dimanfaatkan adalah santan, kemudian limbah ampas kelapa tidak dimanfaatkan dan dibuang sehingga menimbulkan pencemaran lingkungan serta menimbulkan penyakit seperti tumbuhnya lalat, dan nyamuk.

2. Usaha produksi dan penjualan pudak yang dilakukan kedua kelompok usaha tersebut hanya sebatas penjualannya di Kabupaten Gresik, karena kedua kelompok tersebut kesulitan untuk memasarkan hasil produksi dan penjualannya keluar Kabupaten lainnya. Harapan dari kedua kelompok usaha produksi dan penjualan pudak dapat dipasarkan keluar Kabupaten agar produksi tiap harinya bertambah. Seiring dengan bertambahnya produksi pudak maka akan mendapatkan laba yang cukup besar.

3. Usaha produksi dan penjualan pudak yang dilakukan kedua kelompok usaha tersebut belum memiliki catatan pembukuan dan keuangan yang baik, selama ini kedua kelompok usaha transaksi penjualan usahanya tidak memakai pembukuan hanya sekedar mendapatkan uang dari hasil jualan setiap harinya, kemudian uang yang didapatkan di gunakan kembali sebagai pembelian bahan baku untuk produksi pudak.

4. Kedua kelompok usaha produksi dan penjualan pudak sebagian besar berlatar belakang pendidikan menengah atas, usaha yang dirintis selama ini meneruskan usaha dari orang tuanya yang sudah berjalan sampai saat ini. Sehingga produksi dan penjualan pudak memakai model konvensional. Ketrampilan untuk melakukan inovasi ataupun terobosan baru untuk memanfaatkan limbah ampas kelapa manjadi tepung untuk digunakan sebagai 
Suwanto $^{1}$, Roihatul Zahroh ${ }^{2}$, Dkk.

bahan baku pembuatan roti kelapa dan pudak belum ada ide yang ada pada kedua kelompok usaha tersebut.

Melalui program (PKM) diharapkan dapat membantu mengatasi permasalahan yang ada selama ini, dan mampu membekali serta mendampingi kedua kelompok usaha produksi dan penjual pudak menjadi pengusaha tangguh/mandiri yang akan mampu beradaptasi dengan perubahan-perubahan teknologi, dan ekonomi pasar yang ada dimasa mendatang. Langkahlangkah yang akan dilakukan tim pengusul program PKM dengan kedua kelompok usaha produksi dan penjual pudak adalah sebagai berikut;

a. Dukungan sepenuhnya dari kedua kelompok usaha produksi dan penjual pudak yang beralamatkan di Kelurahan Sukodono dan Kelurahan Tlogopojok Kecamatan Gresik Kabupaten Gresik dalam pelaksanaan program PKM.

b. Tim pelaksana program PKM akan selalu berkomunikasi dan berkoordinasi dalam upaya mewujudkan harapan/menentukan jawaban atas permasalahan dari kedua kelompok usaha produksi dan penjualan pudak.

c. Hasil komunikasi dan koordinasi dengan kedua kelompok usaha produksi dan penjualan pudak akan dijadikan sebagai pola dasar problem solving/acuan pelaksanaan program PKM.

d. Tim pelaksana program PKM akan melaksanakan pendampingan secara intensif dengan kedua kelompok usaha produksi dan penjual pudak selama kurun waktu delapan bulan dengan berbagai kegiatan seperti (1) memberikan pengetahuan melalui tutoring serta praktek langsung tentang manfaat ampas kelapa menjadi tepung kelapa, kemudian tepung kelapa digunakan sebagai bahan baku pembuatan kue makanan seperti roti kelapa dan pudak; (2) memberikan pengetahuan melalui tutoring serta praktek langsung tentang sistem pemasaran pembelian dan pembayaran, sehingga pembeliaan roti kelapa dan pudak mudah diakses melaui website e-comersial tanpa konsumen datang langsung ke tempat penjualnya; (3) memberikan pengetahuan melalui tutoring tentang penentuan harga pokok produksi dan harga jual produk, sehingga kedua kelompok usaha tersebut mudah untuk mengetahui laba dan kerugiannya setiap bulan sekali.

\section{SOLUSI DAN TARGET}

Solusi yang ditawarkan dalam usulan program PKM adalah menjawab permasalahan dari kedua kelompok usaha produksi dan penjulan pudak dengan melakukan tutoring dan tindakan secara nyata sehingga bisa dirasakan oleh kedua kelompok usaha tersebut. Adapun 
Suwanto $^{1}$, Roihatul Zahroh ${ }^{2}$, Dkk.

tutoring dan tindakan yang dilakukan oleh tim pengusul program PKM dalam meretas permasalahan seperti; (1) memberikan pengetahuan melalui tutoring serta praktek langsung tentang manfaat ampas kelapa dan cara mengolah ampas kelapa menjadi tepung kelapa, yang dapat dimanfaatkan kembali sebagai bahan baku pembuatan roti kelapa dan pudak; (2) memberikan pengetahuan melalui tutoring serta praktek langsung tentang sistem pemasaran pembelian dan pembayaran, sehingga pembeliaan roti kelapa dan pudak mudah diakses melaui website e-comersial tanpa konsumen datang langsung ke penjualnya (Wulanningrum, Helilintar, Aswi, \& Zainul Karim, 2017); (3) memberikan pengetahuan melalui tutoring tentang penentuan harga pokok produksi dan harga jual produk, sehingga kedua kelompok usaha tersebut mudah untuk mengetahui laba dan kerugiannya setiap bulan sekali.

Jenis luaran berdasarkan solusi yang ditawarkan oleh tim pengusul program PKM untuk menjawab permasalahan dari kedua kelompok usaha produksi dan penjual pudak dapat dicapai antara lain;

1. Transfer pengetahuan oleh tim pengusul program PKM tentang manfaat dari limbah ampas kelapa, jenis luaran yang diharapkan antara lain:

a. Limbah ampas kelapa dapat dimanfaatkan sebagai tepung kelapa. Adapun pengolahannya dengan cara mencuci ampas kelapa dengan bersih, merebus ampas kelapa, mengeringkan ampas kelapa kemudian ampas tersebut ditumbuk atau digiling sampai halus sehingga mendapatkan tepung kelapa.

b. Tepung kelapa dapat digunakan sebagai bahan baku untuk produksi roti kelapa dan pudak.

c. Produksi roti kelapa dikemas dengan toples yang sudah ditempeli stiker, stiker telah didesain dengan penampilan yang menarik, sedangkan produksi pudak dikemas dengan pelepa pinang dengan desain secara menarik.

2. Dalam bidang pemasaran, jenis luaran yang diharapkan adalah:

a. Pembuatan website sebagai media promosi/pemasaran secara online.

b. Kelompok usaha produksi dan penjualan pudak mampu melakukan pemasaran secara online.

3. Dalam bidang manajemen, jenis luaran yang diharapkan adalah:

a. Pelatihan tentang manajemen pemasaran dan penentuan harga pokok produksi dan harga jual produk. 
Suwanto ${ }^{1}$, Roihatul Zahroh ${ }^{2}$, Dkk.

\section{METODE PELAKSANAAN}

Berdasarkan hasil wawancara dan kesepakatan bersama antara kedua kelompok usaha produksi dan penjualan pudak dengan tim pengusul PKM, masalah yang dialami kedua kelompok usaha tersebut dan harus dicari solusi untuk memecahkan masalah. Adapun masalah dan solusi yang harus dipecahkan oleh tim pengusul PKM ini seperti; (1) memberikan pengetahuan melalui tutoring serta praktek langsung tentang manfaat ampas kelapa menjadi tepung, kemudian tepung kelapa digunakan sebagai bahan baku pembuatan roti kelapa dan pudak; (2) memberikan pengetahuan melalui tutoring serta praktek langsung tentang sistem pemasaran pembelian sampai pembayaran, sehingga pembeliaan dan pembayaran mudah diakses melalui website e-comersial tanpa konsumen datang langsung ke pembelinya; (3) memberikan pengetahuan melalui tutoring tentang penentuan harga pokok produksi dan harga jual produk, sehingga kedua kelompok usaha tersebut mudah untuk mengetahui laba dan kerugian setiap bulan sekali. Adanya program PKM ini diharapkan kedua kelompok usaha tersebut mendapatkan nilai tambah berdasarkan hasil produksinya. Meningkatkan omset yang lebih banyak karena pemasaran dilakukan secara online melalui website e-comersial sehingga masyarakat luar Kabupaten mudah untuk mengaksesnya, serta dapat mengetahui laba dan kerugihan setiap bulan sekali dikarenakan telah memahami cara menentukan harga pokok produksi dan harga jual produk.

Secara rinci, prosedur kegiatan yang akan dilakukan oleh tim pengusul PKM ini adalah sebagai berikut;

1. Memberikan pengetahuan melalui tutoring serta praktek langsung tentang manfaat ampas kelapa menjadi tepung, kemudian tepung kelapa digunakan sebagai bahan baku pembuatan roti kelapa dan pudak. Materi yang diberikan terdiri dari;

a. Dampak pembuangan limbah ampas kelapa bagi kesehatan dan lingkungan

b. Kandungan gizi tepung ampas kelapa sebagai bahan pangan sumber serat

c. Diet tepung kelapa bagi penderita penyakit hiperglikemik

d. Teori tentang pembuatan tepung kelapa serta pembuatan roti kelapa dan pudak.

2. Memberikan pengetahuan melalui tutoring serta praktek langsung tentang sistem pemasaran pembelian dan pembayaran secara online. Materi yang diberikan terdiri dari;

a. Materi tentang pembuatan website e-comersial

b. Praktek tentang pembuatan website e-comersial 
3. Memberikan pengetahuan melalui tutoring serta praktek tentang penentuan harga pokok produksi dan menentukan harga jual produk, memberikan tutoring tentang manajemen pemasaran produk. Materi yang diberikan terdiri dari;

a. Materi dan praktek menghitung biaya bahan baku, tenaga kerja langsung, biaya over head produksi.

b. Materi tentang manajemen pemasaran.

Adapun partisipasi kedua kelompok usaha mitra dalam program PKM ini sebagai berikut:

1. Menyiapkan tempat untuk penyuluhan program PKM

2. Mengumpulkan limbah ampas kelapa yang tidak dipakai

3. Menyediakan alat penumbuk tepung

4. Menyiapkan bahan baku sebagai pembuatan roti kelapa dan pudak

5. Menyiapkan alat-alat untuk produksi pembuatan roti kelapa dan pudak

6. Berpartisipasi aktif pada program PKM yang dilakukan sesuai dengan jadwal dan materi kegiatan baik teori dan praktek.

7. Pada akhir program peserta dapat melakukan produksi dan penjualan roti kelapa dan pudak dengan memanfaatkan bahan baku dari tepung kelapa

8. Mentransfer pengetahuan dan ketrampilan yang diperoleh selama program kegiatan PKM ini kepada masyarakat lainnya, sehingga pada akhirnya dapat menambah pendapatan masyarakat.

Evaluasi semua kegiatan program PKM dengan mengacu pada beberapa indikator dan tolak ukur evaluasi sebagai berikut:

Indikator evaluasi yang digunakan adalah:

1. Kedua kelompok usaha mampu mempratekkan pembuatan tepung ampas kelapa

2. Kedua kelompok usaha mampu mempraktekkan produksi roti kelapa dan pudak dengan bahan baku tepung kelapa.

3. Kedua kelompok usaha mampu mengoperasikan website e-comersial yang digunakan sebagai transaksi pemasaran pembelian dan pembayaran secara online.

4. Kedua kelompok usaha mampu mempraktekkan cara menentuan harga pokok produksi dan menentukan harga jual pokok produk.

Tolak ukur evaluasi yang digunakan adalah:

1. Kedua kelompok usaha mampu melakukan pembuatan tepung ampas kelapa 
Suwanto $^{1}$, Roihatul Zahroh ${ }^{2}$, Dkk.

2. Kedua kelompok usaha mampu melakukan produksi roti kelapa dan pudak dengan bahan baku tepung kelapa.

3. Kedua kelompok usaha mampu mengoperasikan website e-comersial yang digunakan sebagai transaksi pemasaran dan penjualan secara online.

4. Kedua kelompok usaha mampu mempraktekan penentuan harga pokok produksi dan penentuan harga jual produk.

\section{HASIL DAN LUARAN}

Hasil yang telah dicapai dalam kegiatan program kemitraan masyarakat pada tanggal 26 Mei 2018. Adapun kegiatan yang telah dilakukan sebagai berikut:

1. Tim program kemitraan masyarakat telah membuat produk makanan seperti tepung kelapa, roti kelapa dan pudak bahan dasar yang digunakan adalah ampas kelapa, hasil yang telah dibuat mendapatkan hasil dengan kualitas yang baik berdasarkan aroma, rasa dan penampilan dari produk makanan yang telah dibuat. Adapun proses pembuatan produk makanan seperti tepung kelapa, roti kelapa dan pudak dapat dilihat pada gambar di bawah ini.

Diagram Alir Pembuatan Tepung Kelapa
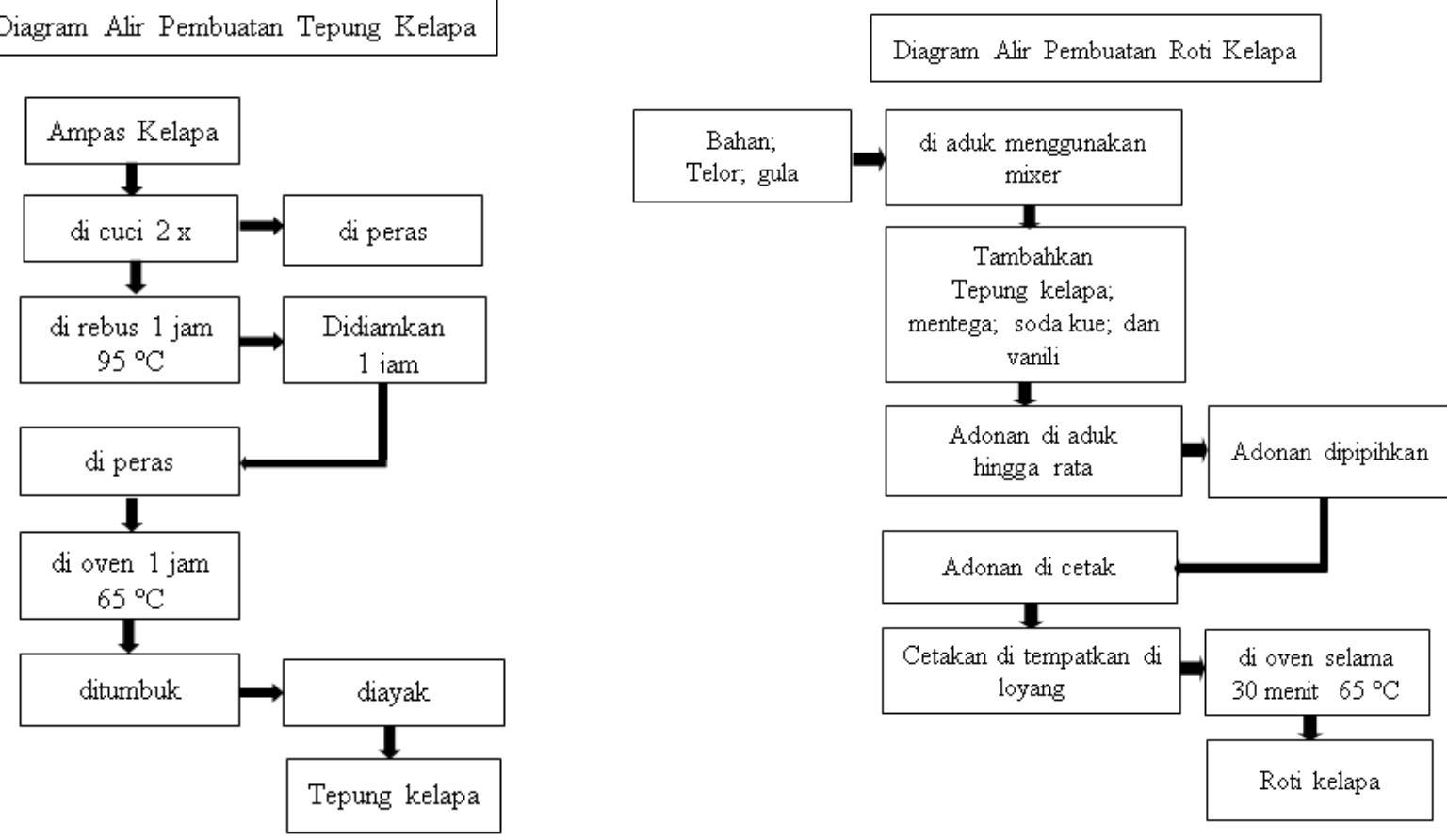

Gambar 1. Alir pembuatan Tepung Kelapa

Gambar 2. Alir Roti kelapa 


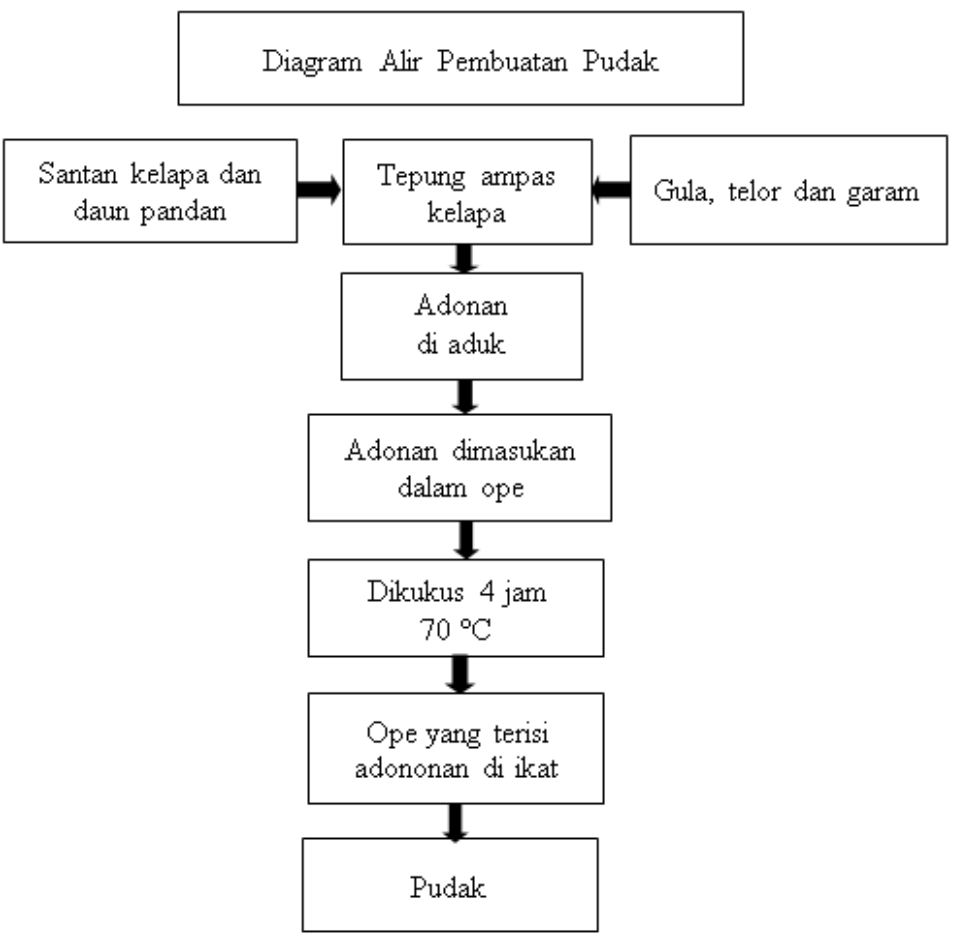

Gambar 3. Pudak

2. Tim program kemitraan masyarakat telah membuat website e-comersial sebagai media pemasaran dari produk makanan yang telah dibuat. Website e-comersial dapat dikelolah oleh mitra kelompok usaha produksi penjual pudak untuk memasarkan hasil produk yang telah dibuat, dan juga website e-comersial ini dapat diakses oleh semua orang yang ingin membeli hasil produksi yang dipasarkan oleh mitra kelompok usaha produksi penjual pudak. Cara mengakses website tersebut melalui laman sebagai berikut http://pkmhibahunigres.com/. Adapun penampilan website e-comersial seperti gambar 4.

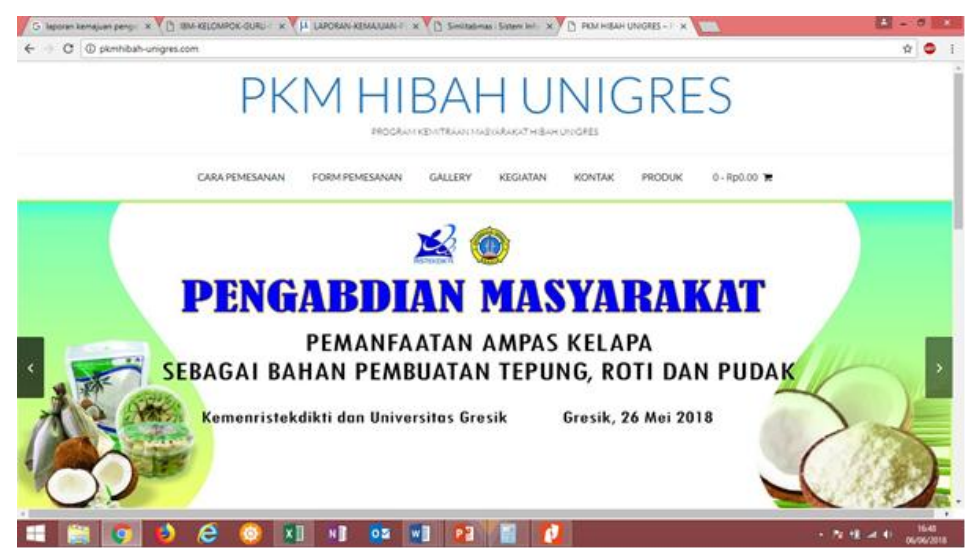

Gambar 4. Website e-comersial

3. Tim program kemitraan masyarakat telah melaksanakan kegiatan tersebut pada tanggal 26 mei 2018 di Balai Kelurahan Sukodono Kecamatan Gresik. Kegiatan tersebut diikuti oleh mitra dan keluarga mitra sebanyak 21 orang. Pelaksanaan kegiatan program tersebut 
Suwanto $^{1}$, Roihatul Zahroh ${ }^{2}$, Dkk.

dibuka secara langsung oleh Kepala Keluarahan Sukodono Kecamatan Gresik, dan dilajutkan dengan pemaparan materi serta praktek oleh tim program kemitraan masyarakat. Antusias kedua mitra dan keluarga mitra sangat bagus hal ini dibuktikan bahwa kedua mitra dan kelurga mitra mengikuti kegiatan tersebut sampai selesai dan juga beberapa pertanyaan yang diajukan oleh mitra keterkaitan dengan materi dan praktek yang diberikan oleh tim program kemitraan masyarakat. Materi dan praktek yang diberikan dalam kegiatan tersebut antara lain; 1) Dampak pembuangan limbah ampas kelapa bagi kesehatan dan lingkungan; 2) Kandungan gizi tepung ampas kelapa sebagai bahan pangan sumber serat; 3) Diet tepung kelapa bagi penderita penyakit hiperglikemik; 4) Teori tentang pembuatan tepung kelapa, roti kelapa dan pudak; 5) Materi dan praktek tentang pembuatan website e-comersial; 6) Materi dan praktek menghitung biaya bahan baku, tenaga kerja langsung, biaya over head produksi; 8) Materi tentang manajemen pemasaran. Adapun kegiatan selama kegiatan program kemitraan masyarakat dapat dilihat pada gambar 5 .
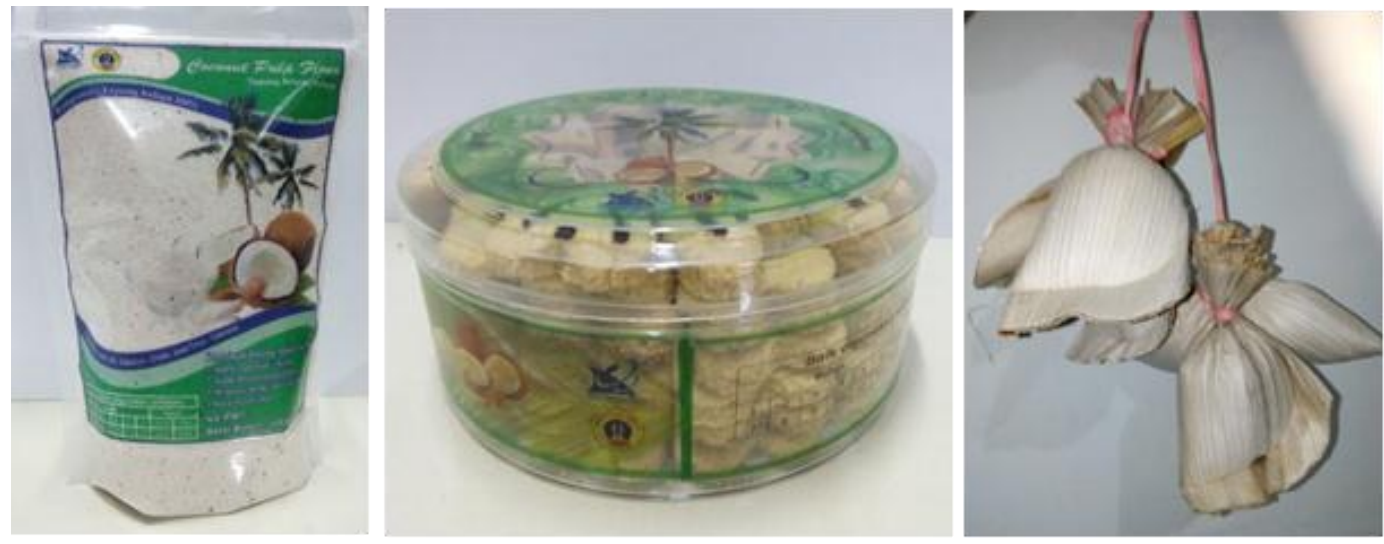

Gambar 5. Produk tepung kelapa, roti kelapa dan pudak berbahan dari ampas

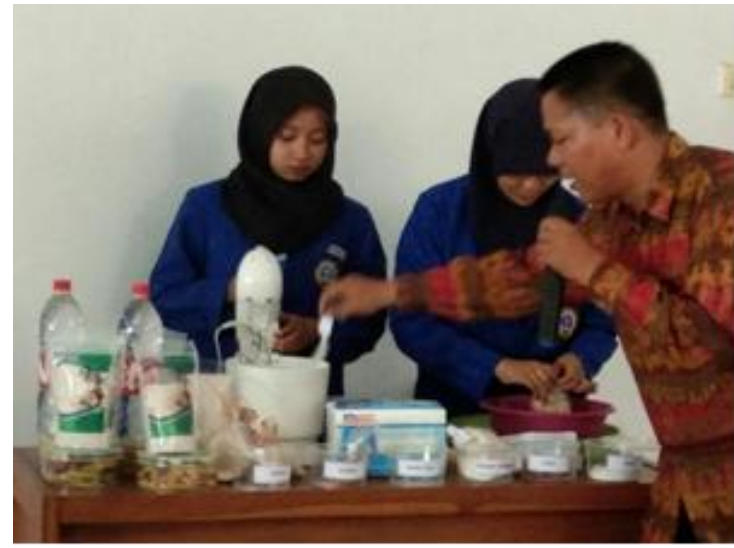

Gambar 6. Demonstrasi pembuatan produk

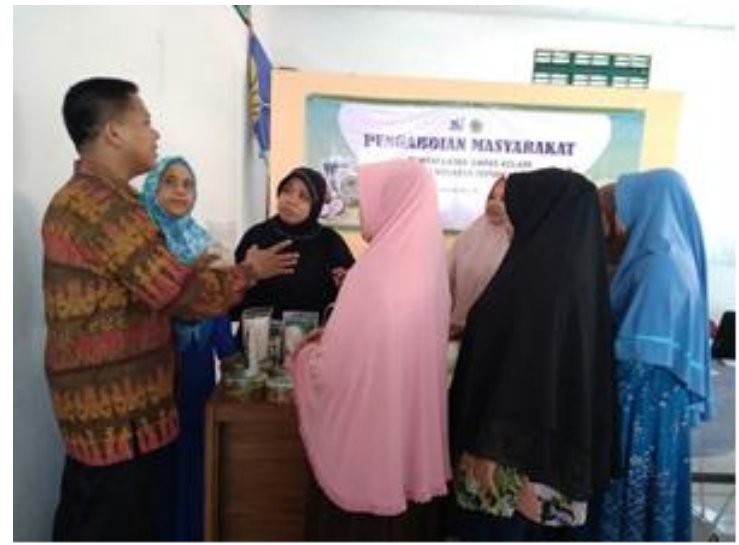

Gambar 7. Penjelasan oleh ketua tim PKM 


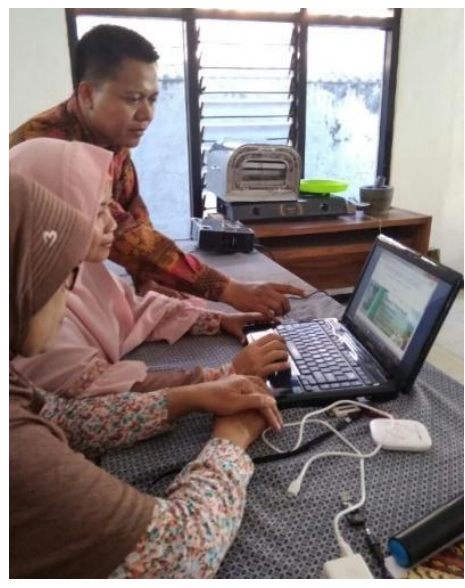

Gambar 8. Pendampingan manajemen pemasaran secara e-comersial

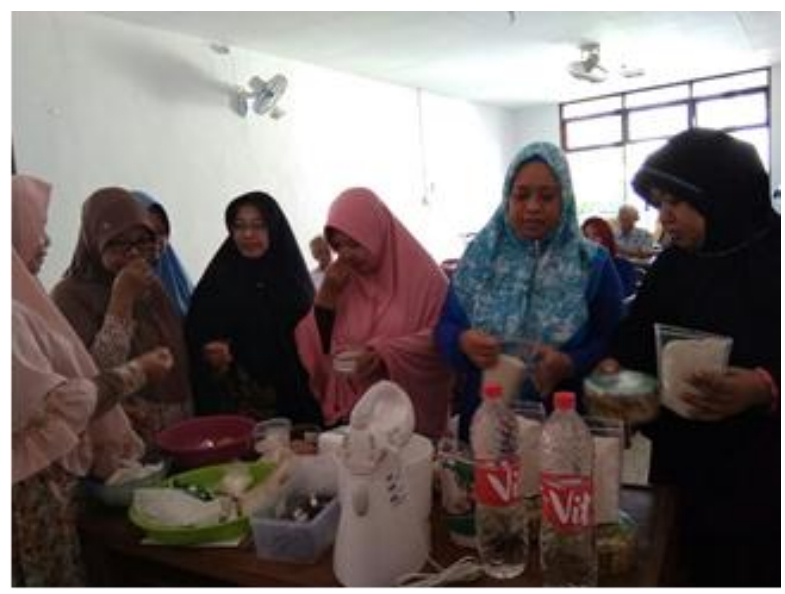

Gambar 9. Pameran produk makanan

4. Hasil kegiatan program kemitraan masyarakat telah dipublikasikan di media Radar Bangsa baik cetak maupun online. Adapun hasil publikasi yang di muat di radar bangsa berupa cetakan dapat dilihat pada gambar 8 dan dapat diakses juga melalui alamathttps://radarbangsa.co.id/dosen-sekaligus-peneliti-universitas-gresik-berikanpenyuluhan-tepung-roti-dan-pudak-dari-limbah-ampas-kelapa-reporter-koko/.

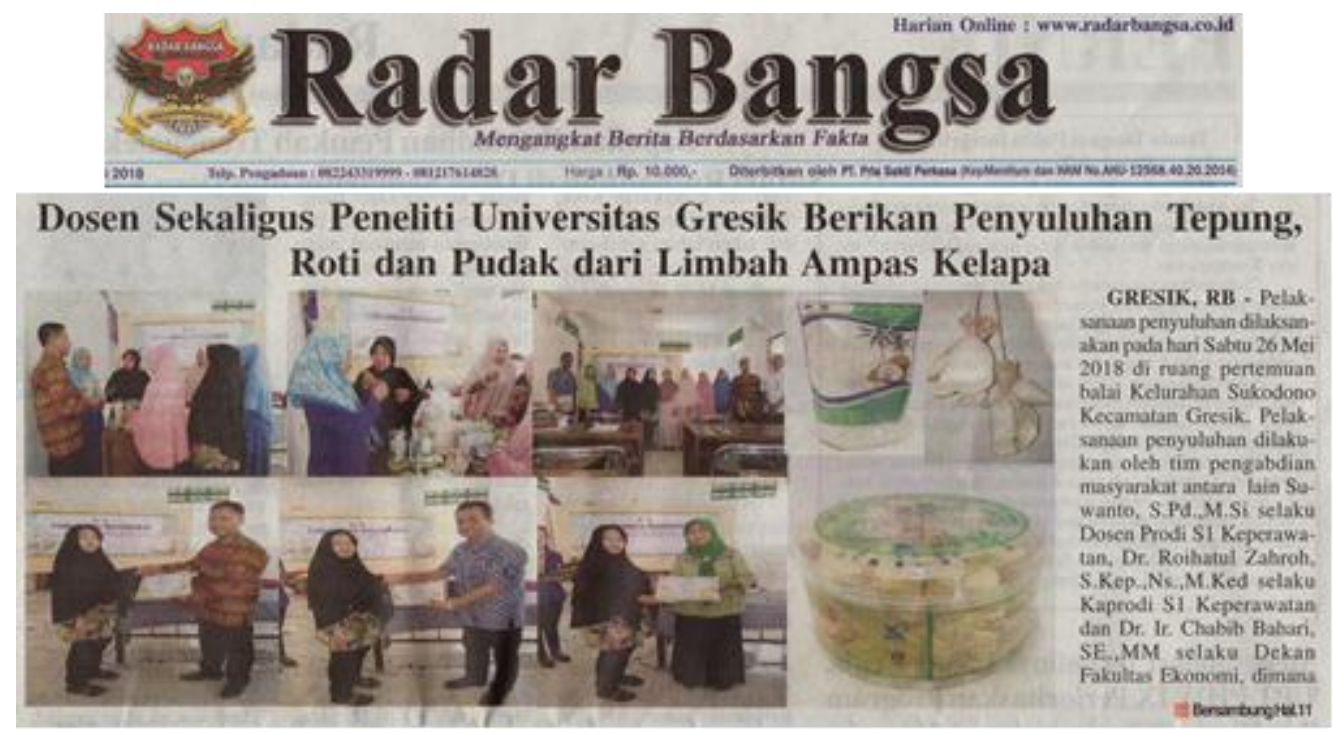

\section{Luaran yang dicapai}

Gambar 10. Hasil Publiksai

Luaran yang dicapai dari hasil program kemitraan masyarakat, dapat berupa laporan kemajuan program kemitraan masyarakat, laporan hasil program kemitraan masyarakat, publikasi di jurnal nasional, publikasi pada media masa cetak, peningkatan daya saing seperti halnya ampas kelapa dibuat menjadi produk makanan seperti tepung kelapa, roti kelapa dan pudak, peningkatan penerapan iptek seperti halnya pemasaran produk menggunakan web site e-comersial, perbaikan tata nilai masyarakat seperti halnya pemanfaatan produk makanan dari 
Suwanto $^{1}$, Roihatul Zahroh ${ }^{2}$, Dkk.

bahan ampas kelapa sebagai kesehatan tubuh, dan hasil produk yang telah dibuat akan di daftarkan sebagai hak cipta karya atau disebut dengan hak kekayaan intelektual.

\section{SIMPULAN}

Setelah pelaksanaan kegitan program kemitraan masyarakat yang telah dilaksanakan oleh tim program kemitraan masyarakat dengan kedua mitra dan keluarga mitra usaha produksi dan penjualan pudak maka dapat diperoleh kesimpulan sebagai berikut.

1. Antusias kedua mitra dan keluarga mitra dalam mengikuti kegiatan tersebut hingga selesai, banyak pertanyaan yang telah diajukan dikarenakan selama ini belum mengenal pemanfaatan ampas kelapa digunakan sebagai produk makanan, tidak perna melakukan pemasaran melalui e-comersial dan tidak perna menghitung harga pokok produksi dan harga jual produk.

2. Pemanfaatan ampas kelapa dapat dibuat produk makanan seperti tepung kelapa, roti kelapa dan pudak dengan aroma yang khas kelapa, rasa kelapa dan penampilannya juga bagus. Adapaun produk makanan tersebut yang telah dibuat maka dapat menambah penghasilan bagi kedua mitra dan keluarga mitra usaha produksi dan penjualan pudak.

3. Penggunaan website e-comersial dapat mempermuda kedua mitra untuk memasarkan hasil produk yang telah dibuat. Adapun manfaat pemasaran menggunakan website ecomersial adalah hemat waktu, hemat uang, dan hemat tenaga.

4. Kedua mitra usaha produksi dan penjualan pudak dapat menghitung biaya bahan baku, tenaga kerja langsung, biaya over head produksi sehingga dapat menimalisir kerugihan, dan mengetahui berapa keuntungan yang telah didapatkan dari hasil produksinya.

\section{DAFTAR RUJUKAN}

Astawan, 2004 dalam Yulvianti Meri, Ernayati Widya, Tarsono, R. Alfian M, 2015.

Pemanfaatan Ampas Kelapa Sebagai Bahan Baku Tepung Kelapa Tinggi Serat Dengan Metode Freeze Drying. Jurnal Integrasi Proses. 5 (2): 101 -

107.http://download.portalgaruda.org/article.php?article $=361507 \&$ val $=7583 \&$ title $=\mathrm{PE}$ MANFAATAN\%20AMPAS\%20KELAPA\%20SEBAGAI\%20BAHAN\%20BAKU\%2 0TEPUNG\%20KELAPA\%20TINGGI\%20SERAT\%20DENGAN\%20METODE\%20F REEZE\%20DRYING (5 Mei 2018).

Bonzon, J.A. and J.r. Velasco. 1882. dalam Putri Fajri Meddiati. 2010. Kandungan Gizi dan Sifat Fisik Tepung Ampas Kelapa Sebagai Bahan Pangan Sumber Serat. Jurnal 
Suwanto $^{1}$, Roihatul Zahroh ${ }^{2}$, Dkk.

Teknubuga. 2 (2): $32-$

43.https://journal.unnes.ac.id/nju/index.php/teknobuga/article/view/6402 (5 Mei 2018).

Fauzan Muthia. 2013. Pengaruh substitusi tepung ampas kelapa terhadap kandungan gizi, serat dan volume pengembangan roti. Artikel Penelitian. Fakultas Kedokteran Universitas Diponegoro.

Semarang.http://eprints.undip.ac.id/41840/1/563_MUTHIA_FAUZAN_G2C009001.pdf (5 Mei 2018).

Pratiwi Elsa Desy, Hendrarini Lilik, Amalia Rizki. 2016. Pmanfaatan Limbah Ampas Kelapa (Cocos nucifera Lin) Sebagai Tepung Dalam Pembuatan Mi Basah. Sanitasi,Jurnal Kesehatan Lingkungan. 8(2): 51-

56.journalsanitasi.keslingjogja.net/index.php/sanitasi/article/download/1/1 (5 Mei 2018).

Ramulu dan Rao, 2003 dalam Yulvianti Meri, Ernayati Widya, Tarsono, R. Alfian M, 2015. Pemanfaatan Ampas Kelapa Sebagai Bahan Baku Tepung Kelapa Tinggi Serat Dengan Metode Freeze Drying. Jurnal Integrasi Proses. 5 (2): 101-

107.http://download.portalgaruda.org/article.php?article=361507\&val=7583\&title=PE MANFAATAN\%20AMPAS\%20KELAPA\%20SEBAGAI\%20BAHAN\%20BAKU\%2 0TEPUNG\%20KELAPA\%20TINGGI\%20SERAT\%20DENGAN\%20METODE\%20F REEZE\%20DRYING (5 Mei 2018).

Trinidad P Trinidad et al, 2006. Dietary fiber from coconut flour: A functional food.

Innovative Food Science and Emerging Technologies. 7 (1): 309-

317.https://www.sciencedirect.com/science/article/pii/S1466856406000452 (5 Mei 2018)

Yulvianti Meri, Ernayati Widya, Tarsono, R. Alfian M, 2015. Pemanfaatan Ampas Kelapa Sebagai Bahan Baku Tepung Kelapa Tinggi Serat Dengan Metode Freeze Drying. Jurnal Integrasi Proses. 5 (2): 101-

107.http://download.portalgaruda.org/article.php?article=361507\&val=7583\&title=PE MANFAATAN\%20AMPAS\%20KELAPA\%20SEBAGAI\%20BAHAN\%20BAKU\%2 0TEPUNG\%20KELAPA\%20TINGGI\%20SERAT\%20DENGAN\%20METODE\%20F REEZE\%20DRYING (5 Mei 2018).

Wulanningrum, R., Helilintar, R., Aswi, R. R., \& Zainul Karim. (2017). Penerapan Aplikasi E-Business Sebagai Salah Satu Usaha Peningkatan Penjualan Tanaman. Ppm, 69(1), 6974. Retrieved from http://ojs.unpkediri.ac.id/index.php/PPM.doi:10.29407/ja.v1i1.11730 